\title{
Amended Nomenclature for Strains Related to Mycoplasma laidlawii
}

\author{
By D. G. ff. EDW ARD* \\ Wellcome Research Laboratories, Langley Court, Beckenham, Kent \\ AND E. A. FREUNDT \\ Institute of Medical Microbiology, University of Aarhus, Aarhus, Denmark \\ (Accepted for publication 6 March I970) \\ SUMMARY \\ In an earlier paper it was proposed that a second family be re-established \\ within the Mycoplasmatales for those strains not requiring sterol, and the \\ nomenclature of Sabin, who first made this proposal, was followed in the \\ belief that although unsuitable it was valid. It has now been learnt that \\ the generic name Sapromyces is illegitimate, as it is the name of a genus of \\ fungi. It is therefore proposed that the genus be named Acholeplasma in the \\ family Acholeplasmataceae.
}

Sabin (I94I $a$ ) proposed a classification of the organisms of the pleuropneumonia group in which those organisms, believed to be saprophytes and represented by the sewage isolates of Laidlaw \& Elford (1936), were classified into a separate genus and family from the parasitic species. The genus was named Sapromyces and the family Sapromycetaceae (Sabin, I 94 I $b$ ). The later classification of Edward \& Freundt (1956) recognized only a number of species of one genus Mycoplasma belonging to the order Mycoplasmatales, the sewage and similar strains being named Mycoplasma laidlawii. Recently Edward \& Freundt (1969) proposed the re-establishment of a second genus and family for those strains like $M$. laidlawii which differ from other members of the Mycoplasmatales in not requiring sterol for growth. The proposal was made to facilitate further classification and in the belief that dependence on sterol was a fundamental property. It has received further support from the finding that two species of the new genus have a larger genome size than several species of Mycoplasma (Bak, Black, Christiansen \& Freundt, 1970).

The names given to the second genus and family were those proposed by Sabin, in the belief that although inappropriate they were valid. Following the publication of the paper it has been brought to our attention that Sapromyces is illegitimate, as it is the valid name of a genus of fungi of the order Leptomitales (Fritsch, I893).

It is therefore proposed that the genus to contain those species of the Mycoplasmatales which do not require sterol for growth be named Acholeplasma gen. nov. ( $a$ Gr. = not; chole Gr.n. = bile; plasma Gr.n. = anything moulded or formed), type species Acholeplasma laidlawii (Sabin) comb. nov., and that the genus should be the type of a new family Acholeplasmataceae. The name suggests lack of a requirement for an important constituent of bile, namely cholesterol. The ending -plasma has

* Present address: Bacteriological Laboratory (P.H.L.S.), County Hall, London, S.E.I. 
been chosen in the hope that it will set a precedent for future naming of new genera of Mycoplasmatales, which are now recognized to belong to a distinct biological class of micro-organism, the Mollicutes (Edward \& Freundt, 1967; Edward et al. 1967). Since the species at present classified as Mycoplasma granularum belongs to the new family, it must be renamed Acholeplasma granularum.

We wish to thank Dr G. C. Ainsworth and Professor L. E. Hawker for so quickly pointing out to us the illegitimacy of the first name, and all those who have helped us in arriving at an alternative name for the genus.

\section{REFERENCES}

Bak, A. L., Black, F. T., Christiansen, C. \& Freundt, E. A. (1970). Genome size of mycoplasmal DNA. Nature, London 224, I 209-1210.

Edward, D. G. ff. \& Freund, E. A. (1956). The classification and nomenclature of organisms of the pleuropneumonia group. Journal of General Microbiology 14, 197-207.

EDwARD, D. G. ff. \& FREUNDT, E. A. (1967). Proposal for Mollicutes as name of the class established for the order Mycoplasmatales. International Journal of Systematic Bacteriology 17, 267-268.

Edward, D. G. ff. \& Freundt, E. A. (I969). Proposal for classifying organisms related to Mycoplasma laidlawii in a family Sapromycetaceae, genus Sapromyces, within the Mycoplasmatales. Journal of General Microbiology 57, 39I-395.

Edward, D. G. ff., Freundt, E. A., Chanock, R. M., Fabricant, J., Hayflick, L., Lemcke, R. M., Razin, S., Somerson, N. L. \& Wirtler, R. G. (I967). Recommendations on nomenclature of the order Mycoplasmatales. Science, New York 155, I694-1696.

FrITSCH, K. (I 893). Nomenclatorische Bemerkungen. Osterreichische Botanische Zeitung 43, 420-42I.

Laidlaw, P. P. \& Elford, W. J. (1936). A new group of filterable organisms. Proceedings of the Royal Society B 20, 292-303.

SABIN, A. B. (I94I $a$ ). The filtrable micro-organisms of the pleuropneumonia group. Bacteriological Reviews 5, I-66.

SABIN, A. B. (1941b). The filtrable micro-organisms of the pleuropneumonia group (appendix on classification \& nomenclature). Bacteriological Reviews 5, 33I-335. 